\title{
Sensitivity of three unionid glochidia to elevated levels of copper, zinc and lead
}

\author{
N. Kováts ${ }^{(1)}$, N.-A. Abdel-Hameid ${ }^{(1,2)}$, K. Kovács ${ }^{(1)}$, G. Paulovits ${ }^{(3)}$ \\ Received May 24, 2010 / Reçu le 24 mai 2010 \\ Revised August 1, 2010 / Révisé le 1er août 2010 \\ Accepted August 2, 2010 / Accepté le 2 août 2010
}

Key-words: glochidia, ecotoxicity, copper,

zinc, lead, unionid species

\section{ABSTRACT}

In this study glochidia as most sensitive life-stage of bivalves were used to evaluate the toxicity of copper, zinc and lead. Sensitivity of three species, Anodonta anatina, Pseudanodonta complanata and Unio tumidus were compared to copper and zinc, based on 24 and $48 \mathrm{~h} \mathrm{LC}_{50} \mathrm{~S}$. The copper $24 \mathrm{~h} \mathrm{LC} \mathrm{L}_{50}$ showed the lowest value $\left(26.8 \mu \mathrm{g} \cdot \mathrm{L}^{-1}\right)$ for Unio tumidus glochidia. After $48 \mathrm{~h}$ exposure, close LC $_{50}$ values, 18.9 and $19.0 \mu \mathrm{g} \cdot \mathrm{L}^{-1}$, were recorded for $A$. anatina and $U$. tumidus glochidia, respectively. $U$. tumidus glochidia exhibited the highest sensitivity to zinc $\left(48 \mathrm{~h} \mathrm{LC}_{50}=134.2 \mu \mathrm{g} \cdot \mathrm{L}^{-1}\right)$ followed by $P$. complanata $\left(48 \mathrm{~h} \mathrm{LC}_{50}=\right.$ $201.6 \mu \mathrm{g} \cdot \mathrm{L}^{-1}$ ) and $A$. anatina $\left(48 \mathrm{~h} \mathrm{LC}_{50}=233.5 \mu \mathrm{g} \cdot \mathrm{L}^{-1}\right)$. Toxicity of lead to $P$. complanata glochidia was estimated, 24 and $48 \mathrm{~h} \mathrm{LC} \mathrm{LC}_{50} \mathrm{~s}$ of lead to 374.6 and $260.8 \mu \mathrm{g} \cdot \mathrm{L}^{-1}$, respectively. No observed effect concentrations (NOECs) for the tested metals exhibited species differences. All NOECs exceeded environmental quality standards (EQS), therefore these species are at risk only in such European freshwaters which have extreme concentration of these metals. Synergistic effect was reported for the combinations of $\mathrm{Cu}+\mathrm{Zn}$ and $\mathrm{Cu}+\mathrm{Pb}$, additive effect was reported for $\mathrm{Zn}+\mathrm{Pb}$.

\section{RÉSUMÉ}

Sensitivité de trois glochidies d'unionidés à des niveaux élevés de cuivre, zinc et plomb

\section{Mots-clés :} glochidie, écotoxicité, cuivre, zinc, plomb, espèces d'unionidé
Dans cette étude, les glochidies comme stade de vie le plus sensible de bivalves ont été utilisées pour évaluer la toxicité du cuivre, du zinc et du plomb. La sensitivité de trois espèces, Anodonta anatina, Pseudanodonta complanata et Unio tumidus, aux cuivre et zinc a été comparée, à partir des LC LO $_{50} 24$ et $48 \mathrm{~h}$. La LC LC $_{50} 24 \mathrm{~h}$ du cuivre présente la valeur la plus basse $\left(26,8 \mu \mathrm{g} \cdot \mathrm{L}^{-1}\right)$ pour les glochidies de Unio tumidus. Après $48 \mathrm{~h}$ d'exposition, des valeurs $L_{50}$ proches $\left(18,9\right.$ et $\left.19,0 \mu \mathrm{g} \cdot \mathrm{L}^{-1}\right)$ ont été enregistrées pour les glochidies de $A$. anatina et $U$. tumidus respectivement. Les glochidies de U. tumidus montrent la sensibilité la plus forte au zinc $(48 \mathrm{~h}$ $\left.\mathrm{LC}_{50}=134,2 \mu \mathrm{g} \cdot \mathrm{L}^{-1}\right)$ suivie de $P$. complanata $\left(48 \mathrm{~h} \mathrm{LC} 50=201,6 \mu \mathrm{g} \cdot \mathrm{L}^{-1}\right)$ et A. anatina $\left(48 \mathrm{~h} \mathrm{LC} 50=233,5 \mu \mathrm{g} \cdot \mathrm{L}^{-1}\right)$. La toxicité du plomb vis à vis des glochidies de $P$. complanata a été estimée : $\mathrm{LC}_{50} 24$ et $48 \mathrm{~h}$ respectivement 374,6 et $260,8 \mu \mathrm{g} \cdot \mathrm{L}^{-1}$. Les concentrations sans effet observé (NOECs) pour les métaux

(1) Department of Limnology, University of Pannonia, 8200 Veszprém, P.O. Box 158, Hungary

(2) Department of Zoology, Faculty of Science, Benha University, Benha, P.O. Box 13518, Egypt, nassr65@gmail.com

(3) Balaton Limnological Research Institute of the Hungarian Academy of Sciences, 8235 Tihany, P.O. Box 35, Hungary 
testés montrent des différences selon les espèces. Toutes les NOEC sont audessus du standard de qualité environnementale (EQS), par conséquent ces espèces ne seront à risque que dans les eaux douces européennes où les concentrations de ces métaux seraient extrêmes. Un effet synergique est constaté pour les combinaisons $\mathrm{Cu}+\mathrm{Zn}$ et $\mathrm{Cu}+\mathrm{Pb}$, un effet additif pour $\mathrm{Zn}+\mathrm{Pb}$.

\section{INTRODUCTION}

Although some metals are essential for life (Engel and Sunda, 1979), all metals are toxic at high concentrations and for some there is a narrow range of concentrations between what is essential and what is toxic. Elevated metal concentrations can cause severe reduction or elimination of intolerant species, thereby having a significant effect on the diversity and trophic structure of the biological community (Peterson, 1986). In this study three metals were selected for assessing their toxic effect, all of them might pose potential hazard in Lake Balaton and in freshwater ecosystems in general. In aquatic habitats, copper is a predominant pollutant since the copper based compounds are used as herbicides, algicides, and molluscicides (WHO, 1993). Its levels range from 0.04-294 $\mu \mathrm{g} \cdot \mathrm{L}^{-1}$ (An and Kampbell, 2003) reaching $20000 \mu \mathrm{g} \cdot \mathrm{L}^{-1}$ in critical situations (Goodyear and McNeill, 1999). Organo-zinc compounds are ingredients in several fungicides, antibiotics and lubricants (WHO, 2001). Exposure of aquatic organisms to elevated levels of zinc has been found to induce many hazardous biophysiological alterations as antioxidant stress to Perna perna and Unio tumidus (Cossu et al., 2000; Franco et al., 2006). The necessity to study the ecotoxicological impact of mixture of pollutants on aquatic ecosystems is increasing worldwide (Shaw et al., 2006). The simultaneous exposure to several metals might lead to synergistic or antagonistic effects (Enserink et al., 1991). For example, Hanstčn et al. (1996) found that $\mathrm{Mn}\left(400 \mu \mathrm{g} \cdot \mathrm{L}^{-1}\right)$ had no effect on $\mathrm{Cu}$ and $\mathrm{Cd}$, but increased the toxicity of Zn.

Most freshwater mussels have a complex life cycle including a larval stage, called glochidia, which is an obligatory parasite on fish or other vertebrates (Pennak, 1989). In case of many species they are released from the brooding chambers in the gills (marsupia) of the females into the surrounding water where they will encyst upon a host. They are able to survive in the water from 1 to 14 days searching for the host (Mackie, 1984; ASTM, 2006). Freshwater mussels (family Unionidae) are in serious global decline and in urgent need of protection and conservation (Newton et al., 2008). In line with, this research presents the ecotoxicological testing of copper, lead and zinc alone or in combination on the glochidia as the most sensitive life stage of three freshwater mussels (family Unionidae). Although the toxicity of $\mathrm{Cu}$ and $\mathrm{Zn}$ to the glochidia of different unionids has been examined earlier (Pynnönen, 1995; Hanstčn, 1996; Conners and Black, 2004; Milam et al., 2005; Gillis et al., 2008), the toxicity of $\mathrm{Pb}$ has not been extensively studied. Furthermore, copper, zinc and lead interactions are not yet explained. Three species were selected as test organisms: Anodonta anatina, Pseudoanodonta complanata and Unio tumidus, as they co-exist in Hungarian ponds and lakes. At present there are no data available on the comparison of toxicity exerted by $\mathrm{Cu}$, $\mathrm{Zn}$ and $\mathrm{Pb}$ on these three species. Moreover, $\mathrm{P}$. complanata is a protected species in Hungary, therefore its sensitivity to environmental pollutants is of special concern.

\section{MATERIALS AND METHODS}

\section{> COLLECTION AND LABORATORY CARE OF THE MUSSELS}

A. anatina, $P$. complanata and $U$. tumidus gravid females were collected from Marcali reservoir (South of Lake Balaton) in mid-November, 2009. They were kept in glass aquaria for one week to allow them to get acclimatized to laboratory conditions. The water of the aquaria was changed weekly using water collected from Csigere stream $\left(47^{\circ} 7.081^{\prime} \mathrm{N}, 17^{\circ} 25.244^{\prime} \mathrm{E}\right)$ (near 
Devecser village west Veszprém, Hungary) which contained natural food for the mussels. The aquaria were well aerated, basic water quality parameters were as follows: temperature $16-18^{\circ} \mathrm{C}$, dissolved oxygen 7.08-9.07 mg. $\mathrm{L}^{-1}, \mathrm{pH} 7.98-8.72$, conductivity $825-883 \mu \mathrm{s} \cdot \mathrm{cm}^{-1}$. These parameters were measured using multi $\mathrm{HQ} 40 \mathrm{~d}$ with electrode for each measured item.

\section{> GLOCHIDIA COLLECTION AND TOXICITY TESTING}

Collection of mature glochidia was carried out as prescribed by Johnson et al. (1993). First, the marsupia were flushed with water using $35 \mathrm{~mL}$ syringe. The collected glochidia were washed several times with partially reconstituted hard water, $170 \mathrm{mg} \cdot \mathrm{L}^{-1} \mathrm{CaCO}_{3}$ and $\mathrm{pH} 8.38$ (ASTM, 2006) in order to remove the mucus and dead ones. The viability of each larva was checked prior to use by testing its ability to close the valves while exposed to concentrated $\mathrm{NaCl}$ solution, $240 \mathrm{~g} \cdot \mathrm{L}^{-1}$. This was done by counting the number of larvae with opened valve before and after to the exposure to salt solution. Glochidia collected from three gravid females were pooled, except those of $A$. anatina as only one gravid female could be attained. Only, glochidia with viability $\geqslant 90 \%$ were used for the bioassay.

One hundred glochidia for each replicate were exposed to $100 \mathrm{~mL}$ of five serial concentrations of copper sulphate (in triplicate order) as a source of $\mathrm{Cu}\left(5,10,20,40,80\right.$ and $\left.120 \mu \mathrm{g} \cdot \mathrm{L}^{-1}\right)$ and zinc sulphate as a source of $\mathrm{Zn}\left(50,100,200,400,800\right.$, and $\left.1600 \mu \mathrm{g} \cdot \mathrm{L}^{-1}\right)$. Due to paucity of collected glochidia, only those of $P$. complanata were exposed to serial dilutions of $\mathrm{PbCl}_{2}$ as a source of $\mathrm{Pb}\left(50,100,200,400,800\right.$, and $\left.1600 \mu \mathrm{g} \cdot \mathrm{L}^{-1}\right)$. Also, they were exposed to a mixture of tested metals, Cu $40+\mathrm{Zn} 200 ; \mathrm{Cu} 40+\mathrm{Pb} 400$ and Pb $400+\mathrm{Zn} 200 \mu \mathrm{g} \cdot \mathrm{L}^{-1}$. All tests were done in $250 \mathrm{~mL}$ flasks in a triplicate order at room temperature $\left(20-22{ }^{\circ} \mathrm{C}\right)$ for 24 and $48 \mathrm{~h}$. Flasks were covered to keep out extraneous contaminants and bacteria and also, to minimize evaporation. The distinction between dead and alive glochidia was done by counting the number of larvae with opened valve $(\mathrm{N})$ and then placing some drops of concentrated sodium chloride. The alive glochidia normally close the valve; the glochidia with opened valve were than counted again (M). The percentage of survival was calculated as follows: (M - N/M) 100 . Accordingly, the percentage mortality was recorded. For each test chamber in each treatment, other than the controls, the mortality rate was corrected using Abott's formula (Abott, 1925): $E=100(A-M) /(100-M)$ where $E$ is the mortality rate, adjusted for the controls, $A$ is the mortality in the test and $\mathrm{M}$ is the average mortality in the control treatments.

\section{> STATISTICAL ANALYSIS}

One way analysis of variance (ANOVA) was done using Origin software (Origin 7.5) to get the significant difference $(P \leqslant 0.05)$ between the groups (Sanders et al., 1985). The estimation of toxicant concentration resulting $50 \%$ larval mortality of the exposed organisms ( $\mathrm{LC}_{50} \mathrm{~S}$ ) and its confidence limit were calculated using US EPA probit analysis program version 1.5. No-observed effect concentrations (NOECs), as the uppermost concentration being not significantly different from controls $(P \leqslant 0.05)$, were also calculated, using Origin 7.5 software.

To test the interactive effect of both metals, the theoretically expected effect $(E)$ of the binary mixtures on the test organisms was evaluated using the formula proposed by Kungolos et al. (1999) and Hadjispyrou et al. (2001). It was calculated using the following formula: $E=P_{1}+$ $P_{2}-P_{1} P_{2} / 100$, where $E$ is the theoretical expected effect, $P_{1}$ is the inhibition caused by chemical $A$ and $P_{2}$ is the inhibition caused by chemical $B$. This model is based on the hypothesis that the toxicants act concurrently and not successively on the affected organism (Kungolos et al., 2009). The toxicity of binary mixtures was assessed in triplicate order. The observed toxicity of the chemical mixture $(\mathrm{O})$, which was assessed experimentally, and the expected mixture toxicity $(E)$, which was estimated based on the previous equation were compared. Toxic effect can be considered antagonistic or more than additive (synergistic) only if the observed effect $(O)$ is significantly lower or higher, respectively, than the theoretically expected (E) value at $P \leqslant 0.05$ 


\section{Table I}

Acute copper, zinc and lead as $L C_{50}$ s and no-observed effect concentrations (NOEC) $\left(\mu \mathrm{g} \cdot \mathrm{L}^{-1}\right)$ at 24 and $48 \mathrm{~h}$ for glochidia of some unionid species.

Tableau I

Toxicité du cuivre, zinc et plomb mesurée par la LC $_{50}$ et concentrations sans effet observé (NOEC) $\left(\mu \mathrm{g} \cdot \mathrm{L}^{-1}\right)$ à $24 \mathrm{~h}$ et $48 \mathrm{~h}$ pour les glochidies de quelques espèces d'unionidés.

\begin{tabular}{|c|c|c|c|c|c|c|c|}
\hline \multirow[t]{2}{*}{ Metals } & \multirow[t]{2}{*}{ Species } & \multicolumn{3}{|c|}{$24 h$} & \multicolumn{3}{|c|}{$48 \mathrm{~h}$} \\
\hline & & $\begin{array}{c}\text { Control } \\
\text { survival (\%) }\end{array}$ & $\mathrm{LC}_{50}$ & NOEC & $\begin{array}{c}\text { Control } \\
\text { survival (\%) }\end{array}$ & $\mathrm{LC}_{50}$ & NOEC \\
\hline \multirow{3}{*}{ Copper } & A. anatina & $91.5 \pm 0.8$ & $31.2(21.6-47$ & 9 & $91.4 \pm 0.5$ & $18.9(10.0-31.1)^{\mathrm{a}}$ & 8 \\
\hline & P. complanata & $91.5 \pm 0.7$ & $34.3(29.9-39.4)^{a}$ & 12 & $90.8 \pm 0.5$ & $29.3(25.4-34.0)^{a}$ & 10 \\
\hline & U. tumidus & $93.6 \pm 0.7$ & $26.8(23.2-30.9)^{b}$ & 12 & $90.5 \pm 0.2$ & $19.0(16.2-22.0)^{D}$ & 8 \\
\hline \multirow{3}{*}{ Zinc } & A. anatina & $91.6 \pm 0.8$ & $361.1(314.9-415.5)^{a}$ & 90 & $90.3 \pm 0.5$ & $233.5(199.8-271.9)^{a}$ & 60 \\
\hline & P. complanata & $91.5 \pm 0.7$ & $262.5(230.5-298.9)^{b}$ & 70 & $90.8 \pm 0.5$ & $201.6(175.5-230.5)^{a}$ & 55 \\
\hline & U. tumidus & $93.6 \pm 0.8$ & $180.6(55.4-208.3)^{\mathrm{C}}$ & 60 & $90.5 \pm 0.2$ & $134.2(16.1-153.5)^{b}$ & 50 \\
\hline Lead & P. complanata & $91.5 \pm 0.8$ & $374.6(321.0-440.1)$ & 32 & $90.0 \pm 0.5$ & $260.8(226.0-300.5)$ & 29 \\
\hline
\end{tabular}

Confidence limit indicated between brackets. Control data expressed as Mean \pm SE. Data based on corrected mortality, where corrected mortality $=100(A-M) /(100-M)$ where A mortality of test and M average mortality of control. Means of different superscript articles in same column are significantly different at $P \leqslant 0.05$.

Les limites de confiance sont entre parenthèses. Les données témoins sont des moyennes $\pm \mathrm{SE}$. La mortalité observée est corrigée selon la formule mortalité corrigée $=100(A-M) /(100-M)$ où $A$ est la mortalité du test et $\mathrm{M}$ la mortalité moyenne du témoin. Les lettres en exposant indiquent des différences significatives dans la colonne $(P \leqslant 0,05)$.

\section{RESULTS}

\section{> SINGLE EFFECT OF THE METALS}

Viability of the glochidia in the control were $91.5 \pm 0.8$ and $91.4 \pm 0.5 \%$ for $A$. anatina, $91.5 \pm$ 0.7 and $90.8 \pm 0.5 \%$ for $P$. complanata and $93.6 \pm 0.7$ and $90.5 \pm 0.2 \%$ for $U$. tumidus, after 24 and $48 \mathrm{~h}$ respectively (Table I). The Cu $24 \mathrm{~h} \mathrm{LC}_{50} \mathrm{~S}$ for glochidia of the tested mussels ranged from $26.8\left(23.2-30.9 \mu \mathrm{g} \cdot \mathrm{L}^{-1}\right)$ to $34.3\left(29.9-39.4 \mu \mathrm{g} \cdot \mathrm{L}^{-1}\right)$ being $U$. tumidus as the most and


glochidia showed medium sensitivity, with $24 \mathrm{~h}$ and $48 \mathrm{~h} \mathrm{LC} \mathrm{LC}_{50} \mathrm{~s}$ of 31.2 (21.6-47.3) and 18.9 (10.0-31.1) $\mu \mathrm{g} \cdot \mathrm{L}^{-1}$, respectively. $24 \mathrm{~h}$ and $48 \mathrm{~h}$ NOECs were also calculated from the mortality data, these values fell very close to each other: 9 and $8 \mu \mathrm{g} \cdot \mathrm{L}^{-1}$ for $A$. anatina, 12 and $10 \mu \mathrm{g} \cdot \mathrm{L}^{-1}$ for $P$. complanata and 12 and $8 \mu \mathrm{g} \cdot \mathrm{L}^{-1}$ for $U$. tumidus.

$U$. tumidus glochidia proved to be the most sensitive to $\mathrm{Zn}$, too, with the lowest 24 and $48 \mathrm{~h}$ $\mathrm{LC}_{50} \mathrm{~S}$ of 180.6 (55.4-208.3) and $134.2(16.1-153.5) \mu \mathrm{g} \cdot \mathrm{L}^{-1}$, respectively (Table I). The lowest $\mathrm{Zn}$ sensitivity was reported for the glochidia of $A$. anatina, giving 24 and $48 \mathrm{~h} \mathrm{LC}_{50} \mathrm{~S}$ 361.1 (314.9-415.5) and 233.5 (199.8-271.9) $\mu \mathrm{g} \cdot \mathrm{L}^{-1}$, respectively. For $\mathrm{Zn}$, P. complanata showed medium sensitivity, with 24 and 48 h LC $_{50}$ S of 262.5 (230.5-298.9) and 201.6 (175.5230.5) $\mu \mathrm{g} \cdot \mathrm{L}^{-1}$, respectively. Acute $\mathrm{Zn}$ NOECs at 24 and $48 \mathrm{~h}$ were: 90 and $60 \mu \mathrm{g} \cdot \mathrm{L}^{-1}$ for A. anatina, 70 and $55 \mu \mathrm{g} \cdot \mathrm{L}^{-1}$ for $P$. complanata and 60 and $50 \mu \mathrm{g} \cdot \mathrm{L}^{-1}$ for $U$. tumidus, respectively.

The data in Table I show the $\mathrm{Pb} 24$ and $48 \mathrm{~h} \mathrm{LC_{50 }}$ s to the glochidia of $P$. complanata, being $374.6(321.0-440.1)$ and $260.8(226.0-300.5) \mu \mathrm{g} \cdot \mathrm{L}^{-1}$. Comparing the toxicity of the tested metals, it can be concluded that the order of toxicity towards $P$. complanata glochidia was $\mathrm{Cu}>\mathrm{Zn}>\mathrm{Pb}$. The Pb NOECs calculated for $\mathrm{P}$. complanata glochidia were 32 and $29 \mu \mathrm{g} \cdot \mathrm{L}^{-1}$ after 24 and $48 \mathrm{~h}$, respectively.

\section{> BINARY EFFECT OF THE METALS}

The data presented in Table II show the binary interactive effect of $\mathrm{Cu}, \mathrm{Zn}$ and $\mathrm{Pb}$ on the glochidia of $P$. complanata. The binary interactive effect of $\mathrm{Cu}$ and $\mathrm{Zn}$ resulted in significantly 


\section{Table II}

Comparison between theoretically expected and observed interactive effects of the binary mixtures of copper, zinc and lead on corrected mortality of glochidia of Pseudanodonta glochonata.

Tableau II

Comparaison entre effets interactifs attendus et observés de mélanges binaires de cuivre, zinc et plomb sur la mortalité corrigée des glochidies de Pseudanodonta glochonata.

\begin{tabular}{|l|c|c|c|c|}
\hline & \multicolumn{2}{|c|}{$24 \mathrm{~h}$} & \multicolumn{2}{c|}{$48 \mathrm{~h}$} \\
\hline $\begin{array}{l}\text { Metal interactions } \\
\left(\text { (ug. } \mathbf{L}^{-1} \text { ) }\right.\end{array}$ & $\begin{array}{c}\text { Observed corrected } \\
\text { mortality (O) }\end{array}$ & $\begin{array}{c}\text { Expected corrected } \\
\text { mortality (E) }\end{array}$ & $\begin{array}{c}\text { Observed corrected } \\
\text { mortality (O) }\end{array}$ & $\begin{array}{c}\text { Expected corrected } \\
\text { mortality (E) }\end{array}$ \\
\hline $\mathbf{C u ~ 4 0 ~ + ~ Z n ~ 2 0 0 ~}$ & $85.3 \pm 0.93 \uparrow$ & $64.11 \pm 3.29$ & $90.18 \pm 2.13 \uparrow$ & $74.12 \pm 2.14$ \\
\hline $\mathbf{C u ~ 4 0 ~ + ~ P b ~ 4 0 0 ~}$ & $89.62 \pm 1.88^{+}$ & $82.74 \pm 4.12$ & $92.25 \pm 0.95 \uparrow$ & $85.35 \pm 1.22$ \\
\hline $\mathbf{P b ~ 4 0 0 ~ + ~ Z n ~ 2 0 0 ~}$ & $79.73 \pm 1.51^{+}$ & $69.36 \pm 4.55$ & $87.67 \pm 1.53^{+}$ & $86.21 \pm 1.42$ \\
\hline
\end{tabular}

Where corrected mortality $=100(\mathrm{Mc}-\mathrm{Mt}) / \mathrm{Mc}$. Number of replicates are $3 . \uparrow$ is significantly higher than $\mathrm{E}$, more than additive. ${ }^{+}$Non-significantly higher value of $\mathrm{O}$ than $\mathrm{E}$ means additive effect. Significantly lower $\mathrm{O}$ value than $\mathrm{E}$ means antagonistic effect.

Mortalité corrigée $=100(\mathrm{Mc}-\mathrm{Mt}) / \mathrm{Mc}$. Le nombre de réplicats est de 3 . $\uparrow$ est significativement plus grand qu'un simple effet additif. + Valeur de $\mathrm{O}$ égale à $\mathrm{E}$, simple effet additif. Valeur $\mathrm{O}$ plus petite que $\mathrm{E}$ : effet antagoniste.

higher observed effect in comparison to the expected one, so they most probably exerted synergistic effect. The combination of $\mathrm{Cu}$ and $\mathrm{Pb}$ after $24 \mathrm{~h}$ exposure showed additive effect, whereas after $48 \mathrm{~h}$ their interaction was found to be synergistic. The lowest toxic effect was reported for the combination of $\mathrm{Pb}$ and $\mathrm{Zn}$ (additive effect at both exposure periods).

\section{DISCUSSION}

Sensitivity of the three tested species to $\mathrm{Cu}$ fell in the same range, with minor differences. For $A$. anatina glochidia, $24 \mathrm{~h} \mathrm{LC} 50$ was close to the $40 \mu \mathrm{g} \cdot \mathrm{L}^{-1}\left(24 \mathrm{~h} \mathrm{LC} \mathrm{LO}_{50}\right.$ ) reported earlier by Hanstčn et al. (1996). Although no comparative data are available for $P$. complanata, studies involving different species might indicate that the sensitivity of $P$. complanata and $U$. tumidus also fell in the range generally determined for freshwater bivalves (Jacobson et al., 1997; Wang et al., 2007; Gillis et al., 2008).

Regarding $\mathrm{Zn}$ sensitivity, the tested species exhibited considerably higher differences. $U$. tumidus was the most sensitive species, followed by $P$. complanata and $A$. anatina. $24 \mathrm{~h} \mathrm{LC} 50$ of $U$. tumidus $\left(180.6 \mu \mathrm{g} \cdot \mathrm{L}^{-1}\right)$ was close to the value reported $\left(173.5 \mu \mathrm{g} \cdot \mathrm{L}^{-1}\right)$ for Ceriodaphnia dubia (Cooper et al., 2009). For A. anatina glochidia, the 24 h LC 50 was close to $380 \mu \mathrm{g} \cdot \mathrm{L}^{-1}(24 \mathrm{~h} \mathrm{LC} 50$ ) reported earlier by Hanstčn et al. (1996). The susceptibilities of the glochidia of $A$. anatina and $P$. complanata to $\mathrm{Zn}$ were more or less similar to those reported formerly for A. cygnea (Pynnönen, 1995).

Considering the toxicity of lead, there are no comparative data for $P$. complanata. However, $48 \mathrm{~h} \mathrm{LC}_{50}$ was close to $208.8 \mu \mathrm{g} \cdot \mathrm{L}^{-1}\left(48 \mathrm{~h} \mathrm{LC}_{50}\right.$ ) reported by Cooper et al. (2009) for C. dubia. It is important to analyse if response of the tested glochidia actually indicate environmental risk. Neal et al. (1996) give environmental quality standard (EQS) limits for copper, zinc and lead as follows: $6-10 \mu \mathrm{g} \cdot \mathrm{L}^{-1}$ for copper, $50-75 \mu \mathrm{g} \cdot \mathrm{L}^{-1}$ for zinc and 8-18 $\mu \mathrm{g} \cdot \mathrm{L}^{-1}$ for lead.

Acute copper no-observed effect concentrations (NOECs, $\mu \mathrm{g} \cdot \mathrm{L}^{-1}$ ) at 24 and $48 \mathrm{~h}$ for glochidia of the three species were: $A$. anatina 9 and $8 \mu \mathrm{g} \cdot \mathrm{L}^{-1}, P$. complanata 12 and $10 \mu \mathrm{g} \cdot \mathrm{L}^{-1}$, and $U$. tumidus 12 and $8 \mu \mathrm{g} \cdot \mathrm{L}^{-1}$. These values are well above copper concentrations in Lake Balaton which were measured by Nguyen et al. (2005) and they found that the concentration range varied between 0.22 to $0.59 \mu \mathrm{g} \cdot \mathrm{L}^{-1}$. Although no environmental risk posed by copper is present in Lake Balaton, sensitivity of all three species falls in the environmentally relevant range of 0.5 to $100 \mu \mathrm{g} \mathrm{Cu} \cdot \mathrm{L}^{-1}$ as defined by Bossuyt and Janssen (2003), showing that they can be at risk in some freshwater habitats.

The situation is very similar for zinc. Acute Zn NOECs $\left(\mu \mathrm{g} \cdot \mathrm{L}^{-1}\right)$ at 24 and $48 \mathrm{~h}$ for glochidia of the three species were: 90 and 60 for $A$. anatina, 70 and 55 for $P$. complanata and 60 and 50 
for U. tumidus. As reported by Nguyen et al. (2005) Zn concentration in Lake Balaton fell in the range of $0.22-1.9 \mu \mathrm{g} \cdot \mathrm{L}^{-1}$ which are within EQS limits. Although unionid species seem not to be at risk in Lake Balaton, $\mathrm{Zn}$ levels measured in other freshwater habitats exceed NOEC values recorded in our experiment, meaning that in Europe the ecological risk cannot be neglected.

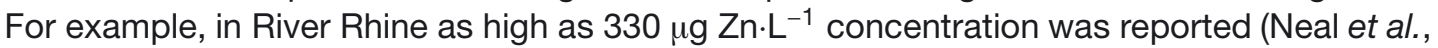
1996) which is considerably higher than these NOEC values.

Ecological risk of $\mathrm{Pb}$ follows a very similar pattern. 24 and $48 \mathrm{~h}$ acute NOECs for $P$. complanata were 32 and $29 \mu \mathrm{g} \cdot \mathrm{L}^{-1}$, respectively. According to Neal et al. (1996), characteristic level in Lake Balaton is between 0.11-3.54 $\mathrm{g} \cdot \mathrm{L}^{-1}$ which fells within EQS. As the reported $\mathrm{Pb}$ NOECs were higher than these EQS and environmental realistic levels in Lake Balaton, $\mathrm{Pb}$ does not pose environmental risk for $P$. complanata in this ecosystem but in some European freshwater habitats environmental concentrations might well exceed these NOEC values (e.g. Neal et al., 1996; Nedjai, 2007).

Regarding the toxicity order, the glochidia of the tested mussels exhibited higher sensitivity for Cu than Zn. Such toxicity order is reported earlier for A. cygnea (Pynnönen, 1995). Also it is reported by Loayza-Muro and Elias-Letts (2007) for Anodontites trapesialis using filtration rate as another end point. The glochidia of $P$. complanata biotest exhibited the following decreasing sensitivity order: $\mathrm{Cu}, \mathrm{Zn}, \mathrm{Pb}$. There are no comparative data for $P$. complanata, but Cooper et al. (2009) reported the same toxicity order for Daphnia magna and Ceriodaphnia dubia.

The data reported herein showed that the interactive effect of $\mathrm{Cu}+\mathrm{Zn}$ were synergistic as indicated by the mortality of $P$. complanata larvae. Synergistic actions of the mixture of $\mathrm{Cu}$ with either $\mathrm{Zn}$ or $\mathrm{Pb}$ were reported by Cooper et al. (2009) using C. dubia and $D$. magna bioassays. However, in our study, the interaction of $\mathrm{Cu}+\mathrm{Pb}$ was found additive. Interaction of metals may be influenced by the tested species, the combination of metals and water quality (Otitoloju, 2002; Kungolos et al., 2009). Spehar and Fiandt (1986) indicated that the same combination of metals (arsenic, cadmium, chromium, copper, mercury and lead) showed different interactive effects depending on both the species exposed and the endpoint tested. Utgikar et al. (2004) reported that the toxic effects of binary mixtures were substantially higher than simple addition of toxicity of the individual metals.

Our study was especially targeted to examine the sensitivity of $P$. complanata. This species is not only protected in Hungary but is listed as 'Near Threatened' on the IUCN red list (IUCN, 2006). Gillis et al. (2008) when testing glochidia of nine unionids found that the endangered species are less tolerant to the contaminants than non-endangered species. However, in our case, $P$. complanata exhibited lower sensitivity than either $U$. tumidus or $A$. anatina.

\section{REFERENCES}

Abott W.S., 1925. A method of computing the effectiveness of an insecticide. J. Econ. Entomol., 18, 265-267.

An Y. and Kampbell D.H., 2003. Total, dissolved, and bioavailable metals at Lake Texoma marinas. Environ. Pollut., 122, 253-259.

American Standard Testing Methods (ASTM), 2006. Standard guide for conducting laboratory toxicity tests with freshwater mussels (E2455-05), ASTM International, West Conshohocken, PA.

Bossuyt B.T.A. and Janssen C.R., 2003. Acclimation of Daphnia magna to environmentally realistic copper concentrations. Comp. Biochem. Physiol. C, 136, 253-264.

Conners D.E. and Black M.C., 2004. Evaluation of lethality and genotoxicity in the freshwater mussel Utterbackia imbcillis (Bivlavia: Unionidae) exposed singly and in combination to chemicals used in Lawn care. Arch. Environ. Con. Toxicol., 46, 362-371.

Cooper N.L., Bidwell J.R. and Kumar A., 2009. Toxicity of copper, lead and zinc mixtures to Ceridophnia dubia and Daphnia magna. Ecotox. Environ. Safe., 72, 1523-1528.

Cossu C., Doyotte A., Babut M., Exinger A. and Vasseur P., 2000. Antioxidant biomarkers in freshwater bivalves, Unio tumidus, in response to different contamination profiles of aquatic sediments. Ecotox. Environ. Safe., 45, 106-121. 
Engel D.W. and Sunda W.G., 1979. Toxicity of cupric ion to eggs of the spot Leiostomus xanthurus and the Atlantic silverside Menidia menidia. Mar. Biol., 50, 121-126.

Enserink E.L., Maas-Diepeveen J.L. and van Leeuwen C.J., 1991. Combined effects of metals; an ecotoxicological evaluation. Water Res., 25, 679-687.

Franco J.L., Trivella D.B., Trevisan R., Dinslaken D.F., Marques M.R.F., Bainy A.C.D. and Dafre A.L., 2006. Antioxidant status and stress proteins in the gills of the brown mussel Perna perna exposed to zinc. Chem.-Biol. Interact., 160, 232-240.

Gillis P.L., Mitchell R.J., Schwalb A.N., McNichols K.A., Mackie G.L., Wood C.M. and Ackerman J.D., 2008. Sensitivity of the glochidia (larvae) of freshwater mussels to copper: Assessing the effect of water hardness and dissolved organic carbon on the sensitivity of endangered species. Aquat. Toxicol., 88, 137-145.

Goodyear K.I. and McNeill S., 1999. Bioaccumulation of heavy metals by aquatic macro-invertebrates of different feeding guilds: a review. Sci. Total Environ., 229, 1-19.

Hanstčn C., Heino M. and Pynnönen K., 1996. Viability of glochidia of Anodonta anatina (Unionidae) exposed to selected metals and chelating agents. Aquat. Toxicol., 34, 1-12.

Hadjispyrou S., Kungolos A. and Anangostopoulos A., 2001. Toxicity, bioaccumulation and effects of organotin, cadmium and chromium on Artemia franciscana. Ecotox. Environ. Safe., 49, 179-186.

IUCN, 2006. IUCN red list of threatened species, http://www.iucnredlist.org.

Jacobson P.J., Neves R.J., Cherry D.S. and Farris J.L., 1997. Sensitivity of glochidial stages of freshwater mussels (Bivalvia: Unionidae) to copper. Environ. Toxicol. Chem., 16, 2384-2392.

Johnson I.C., Keller A.E. and Zam S.G., 1993. A method of conducting acute toxicity tests with the early life stages of freshwater mussels. In: Landis W.G., Hughes J.S. and Lewis M.A. (eds.), Environmental Toxicology and Risk Assessment, STP, American Society of Testing and Materials, Philadelphia, 381-396.

Kungolos A., Samaras P., Kipopoulou A.M., Zoumboulis A. and Sakellaropoulo G.P., 1999. Interactive toxic effects of agrochemicals on aquatic organisms. Water Sci. Technol., 40, 357-364.

Kungolos A., Emmanouil C., Tsiridis V. and Tsiropoulos N., 2009. Evaluation of toxic and interactive toxic effects of three agrochemicals and copper using a battery of microbiotests. Sci. Total Environ., 407, 4610-4615.

Loayza-Muro R. and Elias-Letts R., 2007. Responses of the mussel Anodontites trapesialis (Unionidae) to environmental stressors: Effect of $\mathrm{pH}$, temperature and metals on filtration rate. Environ. Pollut., $149,209-215$

Mackie G.L., 1984. Bivalves. In: Wilbur K.M. (ed.), The Mollusca, Vol. 7, New York Academic Press, 351-418.

Milam C.D., Farris J.L., Dwyer F.J. and Hardesty D.K., 2005. Acute toxicity of six freshwater mussel species (Glochidia) to six chemicals: Implications for daphnids and Utterbackia imbecilis as surrogates for protection of freshwater mussels (Unionidae). Arch. Environ. Con. Tox., 48, 166-173.

Neal C., Smith C.J., Jeffery H.A., Jarvie H.P. and Robson A.J., 1996. Trace element concentrations in the major rivers entering the Humber estuary, NE England. J. Hydrol., 182, 37-64.

Nedjai R., 2007. Evidence of Heavy Metal Pollution in French Jura Lakes: Observed Impacts and Counter measures. In: Information Technologies in Environmental Engineering, Springer, Berlin-Heidelberg, 509-524.

Newton T.J., Ignersoll C.G., Wang N., Augspurger T., Dwer F.J., Barnhart M.C., Neves R.J. and Hammer E., 2008. Differential exposure, duration, and sensitivity of unionoidean bivalve life stages to environmental contaminants. J. N. Am. Benth. Soc., 27, 451-462.

Nguyen H.L., Leermakers M., Osán J., Török S. and Baeyens W., 2005. Heavy metals in Lake Balaton: water column, suspended matter, sediment and biota. Sci. Total Environ., 340, 213-230.

Otitoloju A.A., 2002. Evaluation of the joint-action toxicity of binary mixtures of heavy metals against the mangrove periwinkle Tympanotonus fuscatus var. radula (L). Ecotox. Environ. Safe., 53, 404-415.

Pennak R.W., 1989. Freshwater invertebrates of the United States, 3rd edn., John Wiley and Sons, The Ronald Press Company, New York.

Peterson R.C.J., 1986. Population and guild analysis for interpretation of heavy metal pollution in streams. In: Cairns Jr. J. (ed.), Community Toxicity Testing, Spec. Tech. Publ., 920, American Society for Testing and Materials, Philadelphia, 180-198. 
Pynnönen K., 1995. Effect of pH, hardness and maternal pre-exposure on the toxicity of $\mathrm{Cd}$, $\mathrm{Cu}$ and $\mathrm{Zn}$ on the toxicity of the glochidial larvae of a freshwater clam Anodonta cygnea. Water Res., 29, 247-254.

Sanders D.H., Eng R.J. and Murph A.F., 1985. Statistics, a fresh approach, New York, Mc Graw Hill Company.

Shaw J.R., Dempsey T.D., Chen C.Y., Hamilton J.W. and Folt C.L., 2006. Comparative toxicity of cadmium, zinc and mixtures of cadmium and zinc to daphnids. Environ. Toxiol. Chem., 25, 182-189.

Spehar R.L. and Fiandt J.T., 1986. Acute and chronic effects of water quality criteria-based metal mixtures on three aquatic species. Environ. Toxiol. Chem., 5, 917-931.

Utgikar V.P., Chaudhary N., Koeniger A., Tabak H.H., Haines J.R. and Govind R., 2004. Toxicity of metals and metal mixtures: analysis of concentration and time dependence for zinc and copper. Water Res., 38, 3651-3658.

Wang N., Ingersol C.G., Hardesty D.K., Ivey C.D., Kunz J.L., May T.W., Dwer F.J., Roberts A.D., Augspurger T., Kane C.M., Neves R.J. and Barnhart M.C., 2007. Acute toxicity of copper, ammonia, and chlorine to glochidia and juvenile mussels. Environ. Toxicol. Chem., 26, 2036-2047.

WHO, 1993. The control of schistosomiasis: Second report of the WHO Expert committee, WHO Technical report series, 830, WHO Geneva.

WHO, 2001. Environmental Health Criteria 221: Zinc, WHO Library Cataloguing-in-Publication Data. 